\title{
Assessment of Genetic Variability, Heritability and Genetic Advance for Quantitative Traits in Fenugreek (Trigonella foenum-graecum $\mathbf{L}$.)
}

\author{
Ravi Praksh ${ }^{1}$, D. Singh ${ }^{1}$, B.L. Meena ${ }^{2}$, Reena Kumari ${ }^{1}$ and S.K. Meena ${ }^{2}$ \\ ${ }^{1}$ Department of Plant Breeding and Genetics, S.K.N. College of Agriculture, Jobner-303329, India \\ ${ }^{2}$ ICAR Research Complex for NEH Region, Tripura Centre, Lembucherra - 799210, India \\ *Corresponding author
}

\begin{tabular}{|c|c|}
\hline & A B S T R A C T \\
\hline Keywords & \multirow{4}{*}{$\begin{array}{l}\text { The present investigation was carried out during rabi } 2007-08 \text { at Research Farm, } \\
\text { S.K.N. College of Agriculture, Jobner with } 60 \text { genotypes of fenugreek (Trigonella } \\
\text { foenum-graecum L.) in RBD with three replications to estimate the genetic variability, } \\
\text { heritability and genetic advance for nine quantitative traits. Analysis of variance } \\
\text { indicated significant genetic variability among the genotypes for all the characters in } \\
\text { individuals as well as the pooled basis under both the environments. High magnitude } \\
\text { of PCV and GCV were observed for seed yield per plant in both the environments. } \\
\text { High estimates of PCV, GCV, heritability and genetic advance as percentage of mean } \\
\text { were found for seed yield per plant in both the environment. Based on the present } \\
\text { investigation it is suggested that in breeding programme major emphasis should be } \\
\text { given to pods per plant in both the environmental conditions as it had positive } \\
\text { correlation with seed yield per plant with high direct effect. }\end{array}$} \\
\hline $\begin{array}{l}\text { Trigonella foenum- } \\
\text { graecum } \mathrm{L}, \\
\text { GCV, PCV, } \\
\text { Heritability, } \\
\text { Genetic advance. }\end{array}$ & \\
\hline Article Info & \\
\hline $\begin{array}{l}\text { Accepted: } \\
26 \text { April } 2017 \\
\text { Available Online: } \\
10 \text { May } 2017\end{array}$ & \\
\hline
\end{tabular}

\section{Introduction}

Fenugreek (Trigonella foenum-graecum L.) a member of Fabaceae family, originated from Iran and North India (Smith, 1982). Fenugreek seeds and leaves are strongly aromatic and flavorful. The seeds are bitter in taste, but lose their bitterness if lightly roasted. They are rich in vitamins such as thiamin, folic acid, riboflavin, niacin, vitamins $\mathrm{A}, \mathrm{B} 6$, and $\mathrm{C}$, and are a rich storehouse of many minerals such as copper, potassium, calcium, iron, selenium, zinc, manganese, and magnesium. Fenugreek leaves are a rich source of vitamin $\mathrm{K}$ as well. Fenugreek seeds are a rich source of trigonelline, lysine and 1-tryptophan. The seeds also contain a large amount of saponins and fibers that may account for many of the health benefits of fenugreek like reduces cholesterol, regulates blood sugar and controls diabetes, enhances breast milk production, protects from cancer, maintains healthy testosterone levels, aids digestion, helps with weight loss and fenugreek's use as a natural home remedy. Fenugreek is an indispensable spice due to its nutrition value, taste and flavour and has its unique place in the diet as a vegetable cum spice crop (Gadaginmath, 1992). It seed contains carbohydrates (48\%), proteins $(25.5 \%)$, musilagenous matter $(20.0 \%)$, fats $(7.9 \%)$ and saponin $(4.8 \%)$ (Rao and Sharma, 1987). Fenugreek seeds are 
generally found in most blends of curry powder, spice mixes and meat products. A potential use of fenugreek is for extraction of diosgenin. Diosgenin is a steroid precursor, which is used as a basic material in the synthesis of sex hormones and contraceptives. Fenugreek also has a high degree of medicinal value as it is used in certain Ayurvedic medicines for curing colic flatulence, dysentery, diarrhoea, dyspepsia with loss of appetite. In addition, it is also used for correcting gastric troubles, regulating digestive system, relief in joints pains particularly of old age and as component of concentrate mixture in cattle feeds.

India is the largest producer, consumer and exporter of fenugreek in the world with an annual production of 121,775 tonnes from 96,304 hectares.(National Horticulture Board, 2011-12). Rajasthan leads the country in its production, productivity and export followed by Gujarat, Madhya pradesh and Uttranchal (Spices Board, 2016).

The productivity of the crop is low due to many limiting factors such as lack of superior genotypes or improved cultivars for use in breeding programme to develop potential hybrids. So, there is need for development of new varieties and hybrids with high productivity. The critical assessment of nature and magnitude of variability in the germplasm stock is one of the important pre-requisites for formulating effective breeding methods (Krishna et al., 2007). Improvement in any crop is proportional to the magnitude of its genetic variability present in germplasm. Greater the variability in a population, there are the greater chance for effective selection for desirable types (Vavilov, 1951). Heritability is the portion of phenotypic variation which is transmitted from parent to progeny. Higher the heritable variation, greater will be the possibility of fixing the characters by selection. Hence, heritability studies are of foremost importance to judge whether the observed variation for a particular character is due to genotype or due to environment. Heritability estimates may not provide clear predictability of the breeding value. Thus, estimation of heritability accompanied with genetic advance is generally more useful than heritability alone in prediction of the resultant effect for selecting the best individuals (Johnson et al., 1955).

Therefore, the present investigation was carried out with a view to study the genetic variability, heritabilty and genetic advance for yield and yield component characters in 60 fenugreek genotypes.

\section{Materials and Methods}

The experiment was carried out with 60 genotypes (Table 1) of fenugreek at Research Farm, S.K.N. College of Agriculture, Jaipur, rajasthan, India. The site of the experiment at Jobner. Jobner is situated at an elevation 420 meters above mean sea level at $20^{\circ} 6^{\prime} \mathrm{N}$ and $75^{\circ} 25^{\prime} \mathrm{E}$ which falls under dry climate. A total of 60 germplasm lines were raised in a Randomized Block Design with three replications in two environments namely, (i) normal and (ii) limited moisture condition. In each environment/replication, each genotype was sown in a plot size $2.0 \times 0.3 \mathrm{~m}^{2}$ consisting of one row. The row to row and plant to plant distance was $30 \mathrm{~cm}$ and $10 \mathrm{~cm}$, respectively. Five competitive plants were selected at random for recording the observations on plant height $(\mathrm{cm})$, branches per plant, number of pods per plant, Number of seed per pod, Pod length $(\mathrm{cm}), 1000$-seed weight $(\mathrm{g})$ and Seed yield per plants $(\mathrm{g})$. Data on days to $50 \%$ flowering and Days to maturity was however recorded on whole plot basis. The crop was raised as per the recommended package of practices. Analysis of variance was carried out as per the 
procedure given by Panse and Sukhatme (1985). Genotypic and phenotypic correlation coefficients of variability were estimated according to the Burton and Devane (1953) by using the following formulae.

$\mathrm{PCV}=\frac{\sqrt{\sigma 2_{p}}}{\mathrm{~s}} \times 100 \quad \mathrm{GCV}=\frac{\sqrt{\sigma 2_{g}}}{\mathrm{z}} \times 100$

Where,

PCV = Phenotypic Correlation Coefficient, GCV $=$ Genotypic Correlation Coefficient $\sigma^{2} \mathrm{~g}=$ Genotypic variance $=$ (Mean sum of squares due to genotypes - Error mean sum of squares $) \div$ Replications

$\sigma^{2} \mathrm{p}=$ Phenotypic variance $=\sigma^{2} \mathrm{~g}+\sigma^{2} \mathrm{e}$ $\sigma^{2} \mathrm{e}=$ Environmental variance $=($ Error mean sum of squares) $\div$ Replications

$\overline{\mathrm{x}}=$ General mean

PCV and GCV were classified as suggested by Sivasubramanian and Menon (1973).

Less than $10 \%=$ Low

$10-20 \%=$ Moderate

More than $20 \%=$ High

Heritability in broad sense (h2 (b)) was estimated as per the formulae suggested by Allard (1960).

$\mathrm{h}^{2}(\mathrm{~b})=\frac{(\sigma 2 \mathrm{~g})}{(\sigma 2 \mathrm{p})} \times 100$

The heritability (h2 (b)) was categorised as suggested by Johnson et al., (1955).

$\begin{array}{lll}0-30 \% & = & \text { Low } \\ 31-60 \% & = & \text { Medium } \\ 61 \% \text { and above } & = & \text { High }\end{array}$

Genetic advance (GA) was estimated as per formula given by Allard (1960)

$\mathrm{GA}=\mathrm{K} \times \sigma \mathrm{p} \times \mathrm{h}^{2}(\mathrm{~b})$
Where,

$\mathrm{K}=$ Selection differential at 5 per cent selection intensity which accounts to a constant value 2.06

$\sigma \mathrm{p}=$ Phenotypic standard deviation

Genetic advance over mean (GAM) was calculated using the following formula and was expressed in percentage.

$\mathrm{GAM}=\frac{(G A)}{\overline{\mathrm{x}}} \times 100$

The genetic advance as per cent over mean was categorized as suggested by Johnson et al., (1955).

Less than $10 \%=$ Low $10-20 \%=$ Moderate More than $20 \%=$ High

\section{Results and Discussion}

Analysis of variance (Table 1) revealed significant differences among the genotypes for all the traits indicating presence of significant variability in the genotypes which can be exploited through selection. The analysis of variance revealed that significant variability was present in the genotypes for all the characters under normal and limited moisture condition. This suggested that the material had adequate variability and response to selection may be excepted in the breeding programme for seed yield or any of its supporting characters. These results are in agreement with the findings of Shukla and Sharma (1978) in fenugreek, Dhayal and Bhargava (1997) in cumin, Patni (1983) in wheat, Sadaqat et al., (2003) in rape and Singh and Jat (2007) in cumin in normal and moisture stress conditions. The extent of variability with respect to 9 characters in different genotypes measured in terms of mean, range, genotypic coefficient of variation $(\mathrm{GCV})$, phenotypic coefficient of 
variation (PCV) along with the amount of heritability (h), expected genetic advance and genetic advance as per cent of mean (GAM) are presented in table 2 .

The general mean of the characters was higher in normal environment in comparison to limited moisture condition for each of the trait as expected. Similarly the range was also wider in normal envelopment in comparison to limited moisture $\left(\mathrm{C}_{2}\right)$ for each of the trait. The mean days to $50 \%$ flowering were 57.87 and 52.89 days, respectively in normal and limited moisture condition. The mean days to maturity was observed to be high in normal condition (142.54) and was low in limited moisture condition (133.82). The highest mean plant height was observed in normal condition $(60.50 \mathrm{~cm})$ and $(36.83 \mathrm{~cm})$ in limited moisture condition. Plant height had widest range in limited moisture condition and lowest in normal condition. Mean branches per plant was observed to be high in normal condition (3.59) and was low in limited moisture condition (3.28) although the values are nearly similar. The range was nearly similar in both the environments. The mean number of pod per plant was 27.67 in normal condition and 22.31 in limited moisture condition. The range was narrow in limited moisture condition. The mean seeds per pod were higher in normal condition (16.70) in comparison to limited moisture condition (16.43). The range was nearly similarly in both the environments. The mean pod length was high in limited moisture condition $(8.43 \mathrm{~cm})$ and was low in normal condition $(8.37 \mathrm{~cm})$. The mean 1000-seed weight was high in normal condition (12.07 g) and was low in limited moisture condition $(11.39 \mathrm{~g})$. The mean seed yield per plant was high in normal condition (5.03 g) and was low in limited moisture condition (3.66 g).

Change in the means of character in limited moisture condition in comparison to normal condition was noted. Mean values were higher in normal condition in comparison to limited moisture condition, as expected, for the characters viz., days to $50 \%$ flowering, day to maturity, plant height, pods per plant and seed yield per plant. Pod length had higher mean value in limited moisture condition in comparison to normal condition. This indicated clearly the adverse effect of moisture stress on the character expression by the genotypes. Similar finding was reported by Jat et al., (1990) in wheat under moisture stress condition on seed yield and other traits. The mean values of characters branches per plant, seeds per pod and 1000-seed weight varied little across environmental conditions.

In order to get unit free estimates of variation, coefficients of variation, namely. PCV and GCV were estimated for all the characters (Tables 3). The phenotypic variances were higher than the respective genotypic variances due to the effect of non-heritable components of variance. The phenotypic variances ranged from $1.26 \%$ (days to maturity) to $19.52 \%$ (seed yield per plant) in normal condition and was $1.39 \%$ (days to maturity) to $22.00 \%$ (seed yield per plant) in limited moisture condition. In normal condition highest PCV was recorded for seed yield per plant $(19.52 \%)$ followed by pods per plant $(15.06 \%)$ and moderate value of PCV was recorded for branches per plant $(12.49 \%)$, plant height $(9.65 \%)$ and 1000 -seed weight $(7.08 \%)$. Low PCV values were recorded for seeds per pod $(4.54 \%)$, pods length (4.13), days to $50 \%$ flowering (2.03) and days to maturity $(1.26 \%)$. In limited moisture condition, highest PCV value was recorded for seed yield per plant $(22.00 \%)$ followed by branches per plant $(20.42 \%)$ and pods per plant $(15.09 \%)$, whereas, moderate values of PCV was recorded for plant height $(13.82 \%)$ and 1000-seed weight (7.37\%) and low PCV values were recorded for seeds per pod (6.46\%), pod length (6.34), days to $50 \%$ 
flowering (2.43\%) and days to maturity $(1.39 \%)$.

In normal condition, the highest GCV value was recorded for seed yield per plant $(18.00 \%)$ followed by pods per plant $(14.17 \%)$, moderate value of $\mathrm{GCV}$ was recorded for branches per plant $(10.86 \%)$ and plant height $(9.46 \%)$, while lower values of GCV were recorded for 1000 -seed weight $(5.46 \%)$, pod length $(2.83 \%)$, seeds per pod $(2.51 \%)$, days to $50 \%$ flowering $(0.95 \%)$ and days to maturity $(0.74 \%)$. In limited moisture condition, the highest GCV was recorded for seeds yield per plant $(20.56 \%)$ followed by branches per plant $(19.42 \%)$, moderate values of GCV were recorded for pods per plant $(13.48 \%)$ and plant height (13.11\%). Whereas, low GCV values were observed for 1000 -seed weight $(5.10 \%)$, seeds per pod $(3.82 \%)$, pod length $(3.16 \%)$, days to $50 \%$ flowering (1.07\%) and days to maturity $(0.53 \%)$.

Comparison among the characters indicated that GCV and PCV values varied little across environmental conditions for days to $50 \%$ flowering, days to maturity, pods per plant, 1000-seed weight and seed yield per plant. For plant height, branches per plant, seeds per pod and pod length, the GCV and PCV values were higher in limited moisture condition in comparison to normal condition.

The phenotypic coefficients of variation were in general higher than the genotypic coefficient of variation for all the characters, which indicated effect of environments on the character expression.

It is a common knowledge that the change in mean is associated with higher variation for most of the traits in stress conditions (Paroda and Chopra, 1986). The estimates of coefficients of variations were in general higher in stress environment than in normal.
In both the environments high estimates of variation were observed for traits, plant height, branches per plant, pods per plant and seed yield per plant, thus selection may be more effective for these characters because the response to selection is directly proportional to the variability present in the experimental material. Similar findings were reported by Singh and Jat (2007) in cumin under normal and stress conditions.

Low estimates of variation was observed for days to $50 \%$ flowering, days to maturity, seeds per pod and pod length in both the conditions, which indicated that selection might not be effective for these characters. Similar results were reported by Kohli et al., (1988), Reddy and Reddy (1991), Kailash Chandra et al., (2000) in fenugreek and Singh and Jat (2007) in cumin.

Comparison among the characters indicated that GCV and PCV values varied little across environments for pods per plant and seed yield per plant. For characters plant height, branches per plant and seeds per pod the GCV and PCV values were of higher magnitude in limited moisture condition.

Heritability in broad sense was estimated for all the characters (Table 2 and 3 ) in each of the environments. Heritability estimates varied from one environment to the other. In normal condition, high (>60\%) heritability estimates were recorded for plant height $(95.99 \%)$ followed by pods per plant $(88.60 \%)$, seed yield per plant (85.04) and branches per plant $(75.54 \%)$ and moderate (40-60\%), heritability was recorded for 1000seed weight $(59.32 \%)$ and pods length $(46.96 \%)$, whereas low heritability $(<40 \%)$ estimates were recorded for days to $50 \%$ flowering (21.87\%), seeds per pod $(30.51 \%)$ and days to maturity (34.14\%).

In limited moisture condition, high (>60\%) heritability estimates were recorded for 
branches per plant $(90.50 \%)$ followed by plant height $(90.07 \%)$, seed yield per plant $(87.34 \%)$ and pods per plant $(79.76 \%)$, whereas moderate (40-60\%) estimates of heritability were recorded for 1000-seed weight $(47.75 \%)$. Whereas, low estimates $(<40 \%)$ were recorded for seeds per pod $(34.89 \%)$, pod length $(24.81 \%)$, days to $50 \%$ flowering (19.22\%) and days to maturity $(14.35 \%)$

High estimates of heritability were recorded for plant height, pods per plant, seed yield per plant and branches per plant in both the environment, moderate estimates for 1000seed weight and low estimates were recorded for days to $50 \%$ flowering, seeds per pod and days to maturity in both the environments.

Comparison among the characters indicated that, the heritability values varied across the environmental conditions. For days to $50 \%$ flowering, days to maturity, plant height, pods per plant, pod length and 1000-seed weight, the heritability value was higher in normal condition in comparison to limited moisture condition. The heritability values were higher in limited moisture condition for traits viz., branches per plant, seeds per pod and seed yield per plant in comparison to normal condition.

Expected genetic advance as percentage of mean was calculated for all the characters (Table 3) in each of the environment. In normal condition, genetic advance as percentage of mean ranged from $0.89 \%$ (days to maturity) to $34.19 \%$ (seed yield per plant). Higher values of genetic advance as percentage of mean were recorded for seed yield per plant $(34.97 \%)$ followed by pods per plant $(27.48 \%)$, while, moderate values of genetic advance as percentage of mean were recorded for branches per plant (19.44\%) and plant height (19.09). Low values for genetic advance as percentage of mean were recorded for 1000 -seed weight $(8.66 \%)$, pod length $(4.00 \%)$, seeds per pod $(2.85 \%)$, days to $50 \%$ flowering $(0.91 \%)$ and days to maturity $(0.89 \%)$.

In limited moisture condition, genetic advance as percentage of mean ranged from $0.41 \%$ (days to maturity) to $39.59 \%$ (seed yield per plant). Higher values of genetic advance as percentage of mean was recorded for seed yield per plant (39.59\%) followed by branches per plant $(36.06 \%)$, while moderate values of genetic advance as percentage of mean were recorded for plant height $(25.63 \%)$ and pods per plant $(24.79 \%)$. Low values for genetic advance as percentage of mean were recorded for 1000 -seed weight $(7.25 \%)$, seeds per pod $(4.64 \%)$, pod length $(3.24 \%)$, days to $50 \%$ flowering $(0.96 \%)$ and days to maturity $(0.41 \%)$.

Comparison among the characters indicated that, value of genetic advance as percentage of mean varied little across environmental conditions for days to $50 \%$ flowering, day to maturity, seeds per pod, pod length and 1000seed weight. For characters like plant height, branches per plant and seed yield per plant the genetic advance as percentage of mean values were higher in limited moisture condition in comparison to normal condition. For pods per plant the genetic advance as percentage of mean were higher in normal condition in comparison to limited moisture condition.

The heritability estimates along with the genetic advance are more meaningful. Estimates of heritability serves as an useful guide to the breeder. The breeder is able to appreciate the proportion of variation that is due to the genotype (broad sense heritability) or additive (narrow sense heritability) effects i.e. the heritable portion of variation of the first case, and the portion of genotypic variation that is fixable in pure lines in the later case. If heritability of a character is high 
(> 60\%), selection for such a characters should be fairly easy. This is because there would be close correspondence between genotypic and phenotypic variation due to a relatively smaller contribution of environment to the phenotype, but for a character with a low heritability (<40\%), selection may be considerably difficult or virtually impractical due to masking effect of environment on the genotypic effect.

In present investigation broad sense heritability was observed to be high for plant height followed by pods per plant, seed yield per plant and branches per plant in normal condition and for most of the characters except days to $50 \%$ flowering, days to maturity, seeds per pod, pod length and 1000seed weight in limited moisture condition, which is agreement with earlier reports of high heritability for plant height, 1000-seed weight in normal condition and for branches per plant, 1000-seed weight and seed yield per plant characters in limited moisture condition in cumin by Singh and Jat (2007) and for pods per plant and branches per plant in fenugreek by Mehta et al., (1992); for plant height by Kohli et al., (1988), Kailash Chandra et al., (2000); for 1000-seed weight by Berwal et al., (1996) and Singh (2000) and for seed yield per plant by Sharma et al., (1990), Meena (1994) and Singh (2000) and for most of the characters except pod length by Paramjit Singh and Amardeep Kaur (2007) in fenugreek. While the estimates of heritability changed very little between the environments for traits - plant height and seed yield per plant. The change was considerable for days to maturity, pod length and 1000seed weight. The estimates were higher in the normal environment.

Heritability estimates alone do not provide information on the amount of genetic progress that would result from the selection of the best genotype. Johnson et al., (1955) has pointed out that heritability estimates along with genetic advance were more useful than heritability estimates alone in predicting the response to selection. Therefore, genetic advance as percentage of mean was calculated in order to determine the relative merits of different characters that can be further utilized in the selection programme.

In normal condition high magnitude of genetic advance as percentage of mean was obtained for pods per plant and seed yield per plant which is in agreement with earlier reports of Reddy and Reddy (1991) and Singh (2000) for seed yield per plant and pods per plant. Moderate genetic advance as percentage of mean was observed for plant height and branches per plant are in agreement with the reports of moderate genetic advance for plant height by Singh (2000). Low magnitude of genetic advance as percentage of was observed for days to $50 \%$ flowering, days to maturity, seeds per pod, pod length and 1000-seed weight which is in agreement with the earlier reports of low genetic advance for 1000-seed weight by Kohli et al., (1988), for pod length by Shukla (1978), Kohli et al., (1988) and Singh (2000); for number of seeds per pod by Kailash Chandra et al., (2000).

However, in limited moisture condition characters branches per plant, seed yield per plant and plant height had high heritability along with high genetic advance as percentage of mean which indicated that these characters may be under the control of additive gene action and selection of these characters may be effective. The characters pods per plant had high heritability with moderate genetic advance as percentage of mean. 
Table.1 Pooled ANOVA for different characters of fenugreek genotypes evaluated under normal (C1) and limited moisture $(\mathrm{C} 2)$ conditions

\begin{tabular}{|c|c|c|c|c|c|c|}
\hline \multirow[t]{2}{*}{ S. No. } & \multirow[t]{2}{*}{ Characters } & \multicolumn{5}{|c|}{ Source of variation with d.f. } \\
\hline & & $\begin{array}{l}E \\
1\end{array}$ & $\begin{array}{l}\mathbf{R} \\
4 \\
\end{array}$ & $\begin{array}{c}\mathbf{G} \\
\mathbf{5 9}\end{array}$ & $\begin{array}{r}\mathbf{G} \times \mathbf{E} \\
59\end{array}$ & $\underset{236}{\text { Error }}$ \\
\hline 1. & Days to $50 \%$ flowering & $2225.06^{* *}$ & 2.38 & $3.66^{* *}$ & 0.61 & 1.21 \\
\hline 2. & Days to maturity & $6838.23 * *$ & 4.87 & $8.66 * *$ & 1.26 & 2.55 \\
\hline 3. & Plant height (cm) & $50434.66^{* *}$ & 2.77 & $119.96 * *$ & $52.19 * *$ & 1.97 \\
\hline 4. & Branches per plant & $8.71 * *$ & 0.04 & $0.87 * *$ & $0.89 * *$ & 0.05 \\
\hline 5. & Pods per plant & $2578.70 * *$ & 3.48 & $51.33^{* *}$ & $26.17 * *$ & 2.14 \\
\hline 6. & Seeds per pod & $6.53 * *$ & 0.89 & $1.69 * *$ & $1.14^{* *}$ & 0.57 \\
\hline 7. & Pod length $(\mathrm{cm})$ & 0.32 & 0.22 & $0.39 * *$ & $0.27 * *$ & 0.14 \\
\hline 8. & 1000-seed weight (g) & $41.47 * *$ & 0.43 & $2.64 * *$ & 0.33 & 0.33 \\
\hline 9. & Seed yield per plant $(\mathrm{g})$ & $170.19 * *$ & 0.18 & $2.99 * *$ & $1.40 * *$ & 0.11 \\
\hline
\end{tabular}

$*$ and $* *$ refers to significant at $\mathrm{P}=0.05$ and $\mathrm{P}=0.01$, respectively

Table.2 Mean, range, estimate of variances, coefficients of variation, heritability (broad sense) and genetic advance for yield and other attributes (normal condition)

\begin{tabular}{|c|c|c|c|c|c|c|c|c|c|c|}
\hline \multirow{2}{*}{$\begin{array}{l}\text { S. } \\
\text { No. }\end{array}$} & \multirow[t]{2}{*}{ Characters } & \multirow[t]{2}{*}{ Mean } & \multirow[t]{2}{*}{ Range } & \multicolumn{3}{|c|}{ Estimates of variance } & \multicolumn{3}{|c|}{ Coefficients of variation } & \multirow{2}{*}{$\begin{array}{c}\text { Heritability } \\
\text { \% (bs) }\end{array}$} \\
\hline & & & & $\sigma^{2} e$ & $\sigma^{2} \mathbf{g}$ & $\sigma^{2} p$ & Environment & Genotypic & Phenotypic & \\
\hline 1. & Days to $50 \%$ flowering & 57.87 & $56.00-59.67$ & 1.08 & 0.30 & 1.37 & 1.80 & 0.95 & 2.03 & 21.87 \\
\hline 2. & Days to maturity & 142.54 & $138.00-145.33$ & 2.13 & 1.11 & 3.24 & 1.02 & 0.74 & 1.26 & 34.14 \\
\hline 3. & Plant height $(\mathrm{cm})$ & 60.50 & $46.10-71.07$ & 1.37 & 32.75 & 34.12 & 1.93 & 9.46 & 9.65 & 95.99 \\
\hline 4. & Branches per plant & 3.59 & $2.97-4.37$ & 0.05 & 0.15 & 0.20 & 6.22 & 10.86 & 12.49 & 75.54 \\
\hline 5. & Pods per plant & 27.67 & $20.70-37.63$ & 1.98 & 15.37 & 17.35 & 5.08 & 14.17 & 15.06 & 88.60 \\
\hline 6. & Seeds per pod & 16.70 & $15.37-17.83$ & 0.40 & 0.18 & 0.57 & 3.78 & 2.51 & 4.54 & 30.51 \\
\hline 7. & Pod length $(\mathrm{cm})$ & 8.37 & $7.67-8.92$ & 0.06 & 0.06 & 0.12 & 2.93 & 2.83 & 4.13 & 46.96 \\
\hline 8. & 1000 -seed weight $(\mathrm{g})$ & 12.07 & $10.67-13.72$ & 0.30 & 0.43 & 0.73 & 4.54 & 5.46 & 7.08 & 59.32 \\
\hline 9. & Seed yield/plant $(\mathrm{g})$ & 5.03 & $2.70-6.93$ & 0.14 & 0.82 & 0.96 & 7.44 & 18.00 & 19.52 & 85.04 \\
\hline
\end{tabular}


Table.3 Mean, range, estimate of variances, coefficients of variation, heritability (broad sense) and genetic advance for yield and other attributes (limited moisture condition)

\begin{tabular}{|c|c|c|c|c|c|c|c|c|c|c|c|}
\hline \multirow{2}{*}{$\begin{array}{l}\text { S. } \\
\text { No. }\end{array}$} & \multirow[t]{2}{*}{ Characters } & \multirow[t]{2}{*}{ Mean } & \multirow[t]{2}{*}{ Range } & \multicolumn{3}{|c|}{ Estimates of variance } & \multicolumn{3}{|c|}{ Coefficients of variation } & \multirow{2}{*}{$\begin{array}{c}\text { Heritability } \\
\% \text { (bs) }\end{array}$} & \multirow{2}{*}{$\begin{array}{c}\text { GA as } \\
\text { \%age o } \\
\text { mean }\end{array}$} \\
\hline & & & & $\sigma^{2} e$ & $\sigma^{2} g$ & $\sigma^{2} p$ & Environment & Genotypic & Phenotypic & & \\
\hline 1. & Days to $50 \%$ flowering & 52.89 & $51.00-55.00$ & 1.34 & 0.32 & 1.65 & 2.19 & 1.07 & 2.43 & 19.22 & 0.96 \\
\hline 2. & Days to maturity & 133.8 & $130.33-137.00$ & 2.97 & 0.50 & 3.47 & 1.29 & 0.53 & 1.39 & 14.35 & 0.41 \\
\hline 3. & Plant height $(\mathrm{cm})$ & 36.83 & $22.80-49.83$ & 2.57 & 23.32 & 25.89 & 4.35 & 13.11 & 13.82 & 90.07 & 25.63 \\
\hline 4. & Branches per plant & 3.28 & $2.03-5.57$ & 0.04 & 0.41 & 0.45 & 6.09 & 19.42 & 20.42 & 90.50 & 38.06 \\
\hline 5. & Pods per plant & 22.31 & $14.17-29.23$ & 2.29 & 9.04 & 11.33 & 6.78 & 13.48 & 15.09 & 79.76 & 24.79 \\
\hline 6. & Seeds per pod & 16.43 & $15.00-18.23$ & 0.73 & 0.39 & 1.13 & 5.20 & 3.82 & 6.46 & 34.89 & 4.64 \\
\hline 7. & Pod length $(\mathrm{cm})$ & 8.43 & $7.83-8.98$ & 0.22 & 0.07 & 0.29 & 5.56 & 3.16 & 6.34 & 24.81 & 3.24 \\
\hline 8. & 1000 -seed weight $(\mathrm{g})$ & 11.39 & $9.46-12.62$ & 0.37 & 0.34 & 0.71 & 5.34 & 5.10 & 7.37 & 47.75 & 7.25 \\
\hline 9. & Seed yield/ plant (g) & 3.66 & $1.70-5.62$ & 0.08 & 0.57 & 0.65 & 7.73 & 20.56 & 22.00 & 87.34 & 39.59 \\
\hline
\end{tabular}


Comparison of the genetic advance estimates between the environments indicated that minimum changes in the estimates were observed for seed yield per plant. While the changes was considerable for trait - branches per plant and plant height, while in branches per plant, seed yield per plant and plant height, the estimates increased in stress in comparison to normal environment. The estimate was lower in pods per plant in stress in comparison to normal environment. Days to $50 \%$ flowering, seeds per pod and 1000seed weight had high heritability and low genetic advance as percentage of mean. Days to $50 \%$ flowering and low heritability with low genetic advance as percentage of mean. These finding are in agreement with earlier report of Singh and Jat (2007) in cumin

\section{References}

Allard, R. W. 1960. Principles of Plant Breeding. J. Wiley and Sons, London. pp. 83-88.

Burton, G. W. and Devane, E. H. 1953. Estimating the heritability in tall fescue (Festuca arundinancea) from replicated clonal material. Agronomy J. 45: 478481.

Berwal, K.K., Singh, J.V., Jhorar, B.S., Lodhi, G.P. and Kishor, C. 1996. Character association studies in fenugreek (Trigonella foenum-graecum L.). Annals of Agricultural Biology Research, 1:93-99.

Dhayal, S.L. and Bhargava, S.C. 1997. Screening of drought tolerance in cumin genotypes. Annals of Biology, 13: 7282 .

Gadaginmath, N. B. 1992. Studies related to genetics economic and quality traits and exploitation of heterosis in chilli (Capsicum annuum L.). Ph.D, Thesis, University of Agricultural Sciences, Dharwad.

Jat, K.R., Muraliya, R.N. and Kumar, A.
1990. Physiology of drought tolerance in wheat (Triticum aestivum L.) I growth and yield. Comprehensive Physiology and Ecology, 15: 147-158.

Johnson, H. W., Robinson, H. F. and Comstock, R. E. 1955. Estimates of genetic and environmental variability in soyabean. Agronomy J. 47: 314-318.

Kailash Chandra, Divakara Sastry, E.V., Singh, D. and Chandra, K. 2000. Genetic variation and characters association of seed yield and its component characters in fenugreek. Agriculture Science Digest, 20: 93-95.

Krishna, U. C., Madalageri, M. B., Patil, M. P., Ravindra, M. and Kotlkal, Y. K. 2007. Variability Studies in Green Chilli (Capsicum annuum L.). Karnataka J. Agricultural Sciences. 20: 102-104.

Kohli, V.K., Sharma, O.P. and Singh, J. 1988. Genetic variability, correlation and path analysis in fenugreek. Indian Journal of Horticulture, 45:119-125.

Meena, S.S. 1994. Genetic divergence in germplasm of fenugreek (Trigonella foenum-graecum L.). M.Sc. (Ag.) Thesis, Rajasthan Agricultural University, Bikaner.

Mehta, K.G., Patel, R.H. and Kachhadia, B.T. 1992. Genetic variability and path analysis in fenugreek. Indian Cocoa, Arecanut and Spices Journal 15: 114117.

Paroda, R.S. and Chopra, V.L., 1986. Approaches for incorporating drought and salinity resistance in crop plants. Oxford and IBH Publishing Company Pvt. Ltd., New Delhi, 24-55.

Patni, A.K. 1983. Variability and character association in barley (Hordium vulgare L.) genotypes under normal and moisture stress conditions. M.Sc. (Ag.) Thesis, M.L. Sukhadia University, Udaipur.

Meena, O. P. and Bahadur, V. 2014. 
Assessment of genetic variability, heritability and Genetic advance among tomato (Solanum lycopersicum L.) Germplasm. The Bioscan. 9(2): 15931597.

National Horticulture Board 2013. Data Base of Horticultural crops.Gurgaon, New Delhi.

Panse, V. G. and Sukhatme, P. V. 1985. Statistical methods for agricultural workers. Indian Council Agr. Res., New Delhi.

Rao, P.U. and Sharma, R.S. 1987. An evaluation of protein quality of fenugreek seeds their supplementary effect. Food Chemistry, 24: 1-9.

Reddy, P.V. and Reddy, A.N. 1991. Genetic variability in fenugreek (Trigonella foenum-graecum L.). Indian Cocoa, Arecanut and Spices Journal, 15: 49-52.

Sadaqat, H.A., Tahir, M.H.N. and Hussain, M.T. 2003. Physio genetic aspects of drought tolerance in canola (Brassica napus). International Journal of Agriculture and Biology, 5: 611-614.

Sharma, K.C., Sharma, M.M. and Sharma, R.K. 1990. Nature of variability and association in fenugreek. Indian Journal of Genetics and Plant Breeding, 50: 260-262.

Singh, A. 2000. Estimation of variability for seed yield and its component characters in fenugreek (Trigonella foenumgraecum L.). M.Sc. (Ag.) Thesis,
Rajasthan Agricultural University, Bikaner (Unpublished).

Singh, D. and Jat, N.K. 2007. Genetic variability and heritability for yield and its components under normal, salinity and limited moisture stress conditions in cumin (Cuminum cyminum L.). Published in National Seminar on Production, Development, Quality and Exports of Seed spice-Issues and Strategies held at NRCSS, Tabaji, Ajmer, Rajasthan, p. 12.

Sivasubrahmanian, S. and Menon, P. M. 1973. Genotypic and phenotypic variability in rice. Madras Agricultural J. 60: 1093-1096.

Smitha, R. P. and Basvaraja, N. 2007. Variability and selection strategy for yield improvement in chilli. Karnataka J. Agricultural Sciences. 20(1): 109111.

Smith, A. 1982. Selected materials for turmeric, coriander seed, cumin seed, fenugreek seed and curry powder. Tropical Product Institute, London Co. 165: 7-45.

Shukla, G.P. and Sharma, R.K. 1978. Genetic variability, correlation and path analysis in fenugreek. Indian Journal of Agricultural Sciences, 48: 518-521.

Vavilov, N. I. 1951. Origin, variation, immunity and breeding of cultivated plants. Chronol. Bot. 13: 4-364

\section{How to cite this article:}

Ravi praksh, D. Singh, B.L. Meena, Reena Kumari and Meena, S.K. 2017. Assessment of Genetic Variability, Heritability and Genetic Advance for Quantitative Traits in Fenugreek (Trigonella foenum-graecum L.). Int.J.Curr.Microbiol.App.Sci. 6(6): 2389-2399. doi: https://doi.org/10.20546/ijcmas.2017.606.283 